\title{
Urban Water Governance and Management
}

\author{
Sudhanshu Dubey ${ }^{1}$, Dr. Indrani Chakraborty ${ }^{2}$, Dr. Subhrajit Banerjee ${ }^{3}$ \\ ${ }^{1}$ Student, Maters in Urban and Regional Planning, Faculty of Architecture \&Planning, Dr. A.P.J. AbdulKalam Technical University \\ Lucknow, U.P., India \\ ${ }^{2}$ Professor \& Dean, Faculty of Architecture \&Planning, Integral University, Lucknow \\ ${ }^{3}$ Associate Professor, Faculty of Architecture \& Planning, AKTU, Lucknow
}

\begin{abstract}
The relationship between governance structures for managing water in selected cities and the performance of water policy outcomes (access, quality, tariffs, reliability of service provision, equity, sustainability, etc.) and to explore governance mechanisms that can deal with fragmentation to improve urban water management, including those favouring inter-sectoral complementarities. This implies looking at coordination failures and best practices across water management functions drinking water supply. As such, the paper will focus more specifically on the contribution of governance, urban partnerships and stakeholder engagement as governance instruments that can help address fragmentation of water-related tasks, and foster cooperation to overcome mismatches across water management functions in a given city, between cities and their surroundings, and between water functions and other policy areas.
\end{abstract}

Keywords: Water Policy, Urban water management, stakeholder participation, Governance

\section{Introduction}

Water plays an essential role for development and functioning of the city. It has diverse function such as domestic purposes, discharge of waste, ecological functions like green space management,landscape design, crop cultivation and biodiversity. Water integrates topics such as climatic protection, quality of life, resource and energy efficiency. Wateris the core of Sustainable development.

Water scenario in Urban areas of India:

It is estimated by $2050 \%$ of the population will in Urban centres by the year 2050. The major issue of water is the availability in quantity and quality. According to the Ministry of Urban Development, cities in India require proper attention for water supply. Most of the cities are water deficit and no city having a 24/7 water supply. Out of $5 \%$ of population having access to safe drinking water, only a small percentage of people have access to safe drinking water. The water supply for urban area is 135-150lpcd but the average water supply in Urban local bodies is 69.25lpcd which shows the vast gap between the demand and supply.

Water sources are Surface water and Ground water and the water supply in India has the process of treatment of the water from the source then to the distribution system and finally supplied to the receiver.

\section{Water Governance in India:}

Water governance is the range of political, social, economic and administrative systems that are in place to develop and manage water resources and the delivery of water services, at different levels of society.

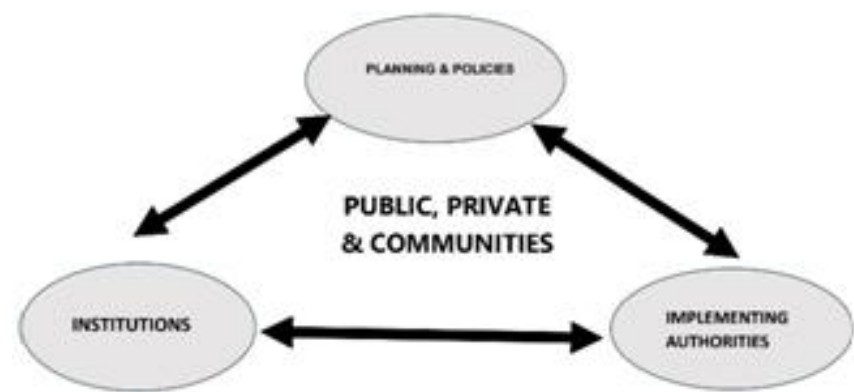

Figure 1: Inter dependency of public, private \& communities

Source-Author

Water related conflicts in India has reached every level and has divided every segment of our society i.e. political parties, states, regions, sub-regions within states, districts, castes, groups and even individual farmers. The victims of the mal-governance resulted conflicted are likely to be the poorest of the poor as well as the sources of the water i.e. rivers, wetlands, acquirers. Rural and urban areas are competing end-users. India: Per Capita Annual Water Availability (cu.m/capita/year)

The Past

$1951-5177$

$2001-1820$

$70 \%$ of global area including large parts of India will become water stressed by 2025 .

\section{Planning \& Policies}

1866 - The government is given the main role in the irrigation and development

1935 - Central government transferred irrigation to the state's governments.

1950 - Beginning of the planned development

1972 - Second irrigation commission report and ARWSP

1980 - The Rashtriya BarhAyog (National Commission on Floods) submitted its report.

1986 - Formulation of NWRC

1987 - National Water Policy (1987) finalized in the first 


\section{International Journal of Science and Research (IJSR) \\ ISSN: 2319-7064}

ResearchGate Impact Factor (2018): 0.28 | SJIF (2019): 7.583

meeting of NWRC

1992 - RGNDWM

1994 - Modified draft of National Water Policy Allocation among states, circulated to the states.

1998 - Water sector review by the GOI and World Bank

1999 - Second meeting of NWRC considered water allocation and river basin authorizes

1999 - Report of the National Commission on integrated water development

2000 - Water vision by India Water Partnership

2002 - National water Policy (2002)

2010 - NRDWP

2012 - National Water Policy 2012

2019 - Jal Shakti Abhyan- JNNURM

ARWSP - The Accelerated Rural Water Supply Programmer was introduced in 1972-73 by the Government of India to assist the States and Union Territories (UTs) to accelerate the pace of coverage of drinking water supply and to supply safe Water in Rural Areas.

RGNWDM - The Accelerated Rural Water Supply Programmer (ARWSP) was given a missionary approach with the launch of the Technology Mission of Drinking Water and Related Water Management, also called the National Drinking Water Mission (NDWM) in 1986. The NDWM was renamed as the Rajiv Gandhi National Drinking Water Mission (RGNDWM) in 1992. The main aim was water supply community planning and Management.

NRDWP- National Rural Drinking Water Programmer (NRDWP) was launched under Bharat Nirman by UPA Government with objective of ensuring provision of safe and adequate drinking water supply through hand-pumps, piped water supply etc. to all rural areas, households and persons.

\section{Urban Water Governance Goals}

- To establish the right to water for all people in a binding manner.

- To guarantee the right to water for coming generations.

- To protect water as a public good belonging to mankind.

- To declare as a core task of governments and their authorities responsible for the respect, protection and fulfillment of the right to water.

- To prevent water from being privatized and commodified.

- To ensure that the human right to water takes precedence international trade law (e.g. WTO).

- To place springs groundwater, rivers and lakes under the comprehensive protection of international law.

- To guarantee women's water-related rights as human rights.

- To protect the local and national water rights of indigenous peoples.

- To enshrine traditional water culture and local water rights (e.g. of nomads) in national law.

- To ensure that the people have a democratic say in determining and deciding national and local water strategies.

- To provide all people both internationally and domestically with effective judicial remedies for demanding fulfillment of the right to water.

\section{Planning \& Policies}

Jal Shakti Abhiyan - The Jal Shakti Abhiyan (JSA) is a time-bound, mission-mode water conservation campaign. The JSA will run in two Phases: Phase 1 from 1st July to 15th September 2019 for all States and Union Territories; and Phase 2 from 1st October to 30th November 2019. The 'Jal Shakti Abhiyan' will focus on five aspects -- water conservation and rainwater harvesting, renovation of traditional and other water bodies, reuse of water and recharging of structures, watershed development, and intensive a forestation.

AMRUT -The scheme was launched by [Prime Minister of India] Narendra Modi in June 2015 with the focus to establish infrastructure that could ensure adequate robust sewage networks and water supply for urban transformation by implementing urban revival projects. Water supply contracts for 494 projects worth have been approved for 500 cities.

SMART CITIES MISSION- Smart Cities Mission, sometimes referred to as Smart City Mission, is an urban renewal and retrofitting program by the Government. The list of 99 smart cities in India have been identified. Water related topics to be addressed and implemented include smart meter management, leakage identification, preventive maintenance, and water quality modelling.

HRIDAY - National Heritage City Development and Augmentation Yojana was launched on 21 January 2015 with the aim of bringing together urban planning, economic growth and heritage conservation in an inclusive manner to preserve the heritage character of each Heritage City. The scheme is being implemented in 12 heritage cities with a total outlay of INR 500 crores focusing on service delivery, including drinking water facility and taps.

National Water Policy: National Water Resources Council was set up on 10th March, 1983 under the Chairpersonship of Prime Minister of India with Union Minister of Irrigation (now Ministry of Jal Shakti) as Vice Chairman. One of the functions of the NWRC is to lay down the national water policy and to review it from time to time. The NWRC adopted the first National Water Policy in September, 1987 and the same was circulated to the central ministries and States for implementation. After NWP 1987, the policy was further reviewed in 2002, and then in 2012, which is the current water policy. The objective of the National Water Policy is to take cognizance of the existing situation of water, to propose a framework for creation of a system of laws and institutions and for a plan of action with a unified national perspective.

National Water Policy 2012: Water is essential for sustenance of ecosystem, and therefore, minimum ecological needs should be given due consideration. Safe Water for drinking and sanitation should be considered as pre-emptive needs, followed by high priority allocation for other basic domestic needs (including needs of animals), achieving food security, supporting sustenance agriculture and minimum eco-system needs. Available water, after meeting the above needs, should be allocated in a manner to promote its 


\section{International Journal of Science and Research (IJSR) \\ ISSN: 2319-7064}

ResearchGate Impact Factor (2018): 0.28 | SJIF (2019): 7.583

conservation and efficient use. Meeting the future needs will depend more on demand management, and hence, this needs to be given priority, especially through (a) evolving an agricultural system which economizes on water use and maximizes value from water, and (b) bringing in maximum efficiency in use of water and avoiding wastages. The impact of climate change on water resources availability must be factored into water management related decisions.

\section{Implementing Authorities \& Institutions}

The National Water Resources Council - The council performs the function of approving water-related policies through the evolution of a consensus.

The National Water Board -The Board assists the National Water Resources Council.

The Ministry of Water Resources- It has a crucial role in drafting the agenda of the National Water Resources Council. The other important function is of giving effect to the decisions.

The Central Water Commission- The Commission acts as the secretariat to the National Water Board. Prepares the basic documents and drafts about water policies. Advising and assisting the ministry.

The Central Ground Water Board- Its main function is to assess groundwater through geo-hydrological surveys and studies, and through the drilling of exploratory tube wells to facilitate such studies. Banks variously use the groundwater assessment information created by the Central Ground Water Board in deciding the credibility of proposals for obtaining loans in regard to the construction of wells and tube wells.

The Central Ground Water Authority- It has legal powers to regulate the exploitation of groundwater in order to ensure that environmental damage due to overexploitation of groundwater is avoided. As stated already, the Union uses its residual powers in regard to the environment. The central groundwater agency thus has no general powers of regulating groundwater use.

The National Committees- These Committees participated in the deliberations on various specialized subjects such as hydrology, irrigation, and drainage, hydraulic research, etc. for deciding research areas as also in evolving a consensus at the professional level, about the problems and possible solutions.

The Specialized National Institutes - Within the ministry of water resources these institutes carry out research on problem areas including issues like the role of forests in hydrology, the quantum of return flows from irrigation, etc. which have a bearing on policies.

Various River Basin Institutes - The Ministry such as the Brahmaputra Board, the Betwa Board, the Upper Yamuna River Board, the Narmada Control Authority, etc. oversees the implementation of the various agreements, tribunal awards, etc.
Various Water Dispute Tribunals - To adjudicate the water disputes in accordance with the terms of reference fixed by the government to formulate the awards. The case law so evolved and the spirit of the award itself has important implications on the future evolution of water policies.

\section{Factors Influencing Water Governance}

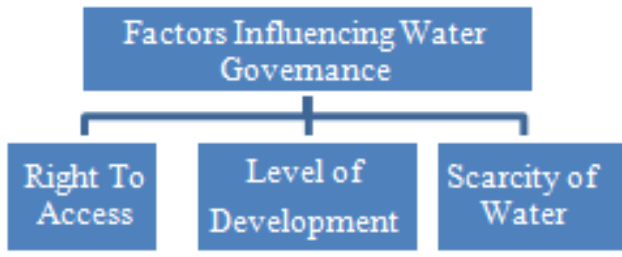

\section{Challenges for Water Governance in India}

Equity, access and allocation

- Conflicts around water quality

- Sand mining in the river basins

- Dams and displaced peoples

- Transboundary water conflicts

- Privatization of water

- Conflicts around water quality

- Sand mining in the river basins

- Dams and displaced peoples

- Transboundary water conflicts

- Privatization of water

- Biodiversity versus irrigation

- Social undercurrents in a water scarce village

- Discrimination in an irrigation project

- Groundwater depletion

- Ecosystem threats due to dams.

- Overlapping of multiple conflicts

- Politics and legislation related with water issues.

\section{Urban Water Management}

Water resource management is the activity of planning, developing, distributing and managing the optimum use of water resources which is a subset of water cycle management. Managing the water resources in an urban area is known as Urban Water Management. Urban water management takes into the notice of thetotal water cycle, promotes the integration of water sources, in the very beginning of the land planning process, and encourages all levels of government and Industries to accede water management and urban planning practices for the welfare of the community, the economy, and the environment. The purpose of urban water management is to create cities and towns that are adaptable, habitable, productive and sustainable. 


\section{International Journal of Science and Research (IJSR) \\ ISSN: 2319-7064}

ResearchGate Impact Factor (2018): 0.28 | SJIF (2019): 7.583

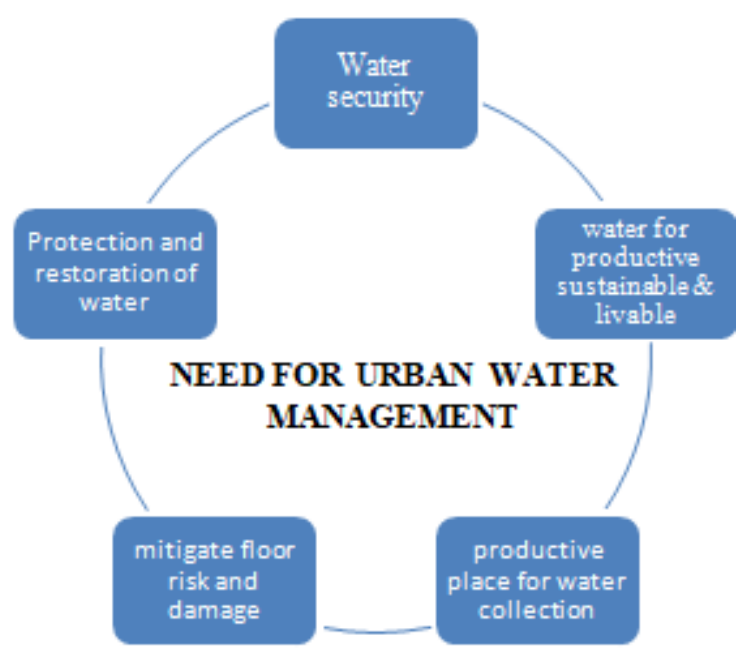

Figure 2: Need for urban water management Source - Author

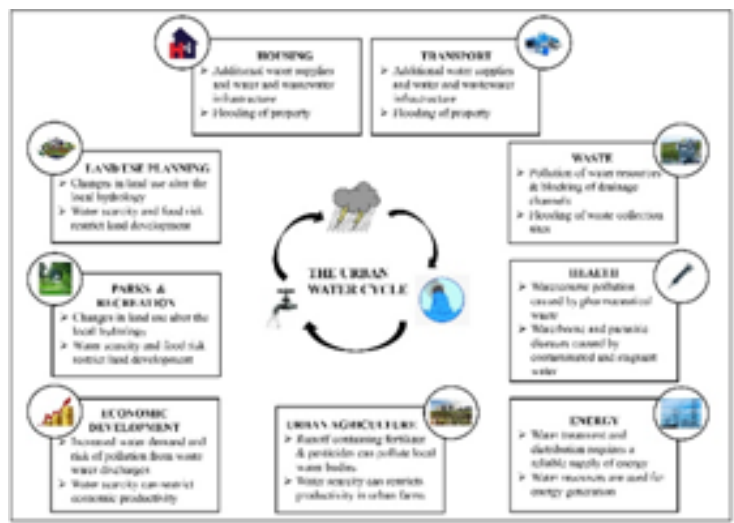

Figure 3: Water cycle in urban area Source-Author

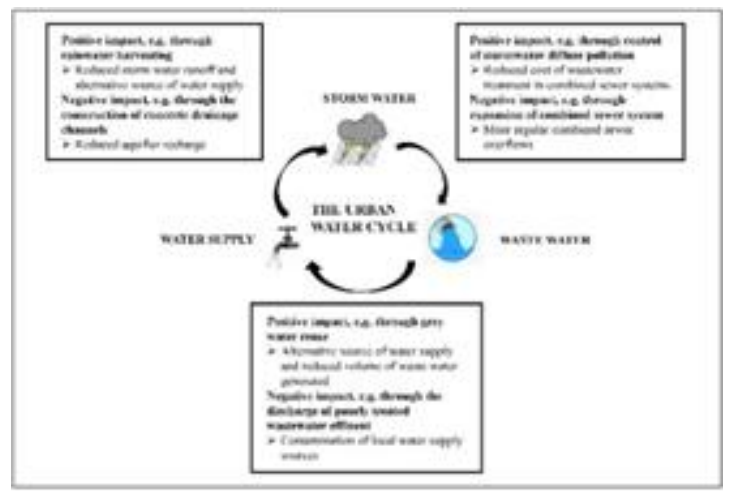

Figure 4: Links between water and other sectors of urban planning:

Source-Author

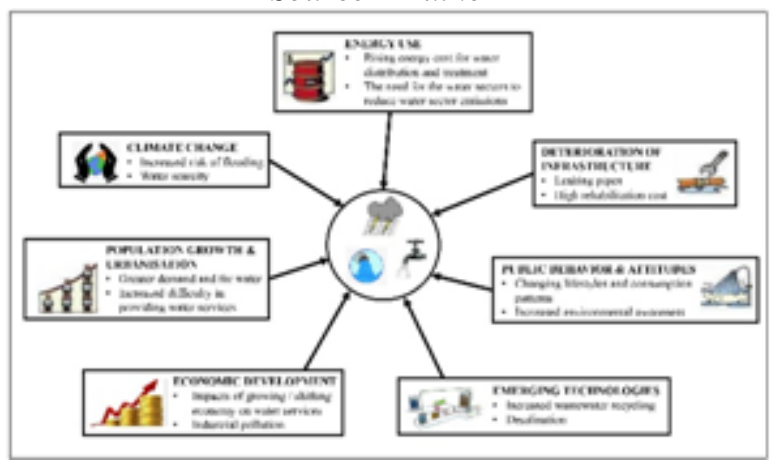

Figure 4: Challenges for urban water management
Source-Author

Approaches to Urban Water Management

- Universalise Access to Water and Sanitation, by Delinking provisioning of service from tenure security Considering phased improvements, where financial resources are limited

- Protection of Water Sources/Sustainable Use of Water

- Demand Management Measures for Water

- Centralised wastewater collection and treatment.

- Physical and institutional integration in the management of the water cycle.

- Integrated land-use planning.

- $100 \%$ Treatment of Wastewater v. Ensuring O \& M of water and sanitation systems

- Awareness Generation and Behaviour Change- for water conservation and hygiene

- AppropriateMechanisms for Regulation of Private Players

- Community Participation

\section{Current Supply Scheme and Management}

The water supply from the government is intermittent and the average duration of running water is 90-120 minutes per day. General inadequacy in water availability can be found in:

a) Calculations of supply and demand that reveal deficits in government water supply

b) High unaccounted for water losses

c) Drops in supply pressure due to large quantities of water released in short durations or the depletion of groundwater affecting pressure in tube wells

d) Issues with water metering and fees

- Water Metering According to the Public Health Engineering Department, there are 384,058 metered connections in the Jaipur water supply scheme. However, about $60 \%$ of meters are not functional.

- Water demand is 462 million litres per day (1/d), water supply from the government is 374 million $1 / \mathrm{d}$, and thus, there is a water supply deficit of 90 million $1 / \mathrm{d}$.

- Drinking Water Quality - Water Quality is a serious concern- specifically Total Dissolved Solids, Nitrate, and Fluoride.

- The Impact of Climate Change -The last twenty years or so have entered into a phase of downward trending rainfall and high variability.

\section{Conclusion}

- An Emphasis on Traditional Water Systems

- Increasing Open Areas

- Conservation of Surface Water.

- Pollution Prevention \& Minimizing the Use of Fresh Water in Industrial Areas

- Curbing chemical pollution of Nitrates \& Fluorides

- Educating the Public

- Groundwater Regulation \& Conservation

- Development of Natural Resource \& Land Use Monitoring System

- Rooftop Rainwater Harvesting

- Investment in Update of Distribution Systems \& Metering

- Conservation of Water in the Irrigation Sector

Volume 9 Issue 7, July 2020 www.ijsr.net 


\section{International Journal of Science and Research (IJSR) \\ ISSN: 2319-7064}

ResearchGate Impact Factor (2018): 0.28 | SJIF (2019): 7.583

- Artificial Recharge from Paved Areas

\section{References}

[1] Water Governance in the Face of Global Change

[2] Water Governance and Management in India

[3] Urban Water Governance for the Twenty-First Century: A Portfolio-Based Approach to Planning and Management

[4] http://publications.iwmi.org/pdf/H042921.pdf

[5] https://www.thehindu.com/opinion/op-ed/rethinkingwater-governancestrategies/article28984738.ece

[6] https://www.indiawaterportal.org/articles/nationalwater-policy-resourceplanning-department-2010

[7] http://www.legalserviceindia.com/article/1420-WaterManagement.html

[8] https://www.epw.in/journal/2019/15/commentary/chall enges-water-governance.html

[9] https://www.un-ihe.org/chair-groups/water-governance

[10] http://iihs.co.in/knowledge-gateway/wpcontent/uploads/2015/07/3_Wat_San.pdf

[11] https://dspace.library.uu.nl/handle/1874/331104

[12] https://www.adriindia.org/adri/india_water_facts

[13] http://mowr.gov.in/about-us/functions

Volume 9 Issue 7, July 2020

www.ijsr.net 